\title{
Science-society dialogue from the start: Participatory research agenda-setting by Science Cafés
}

\author{
Bálint Balázs D, Janka Horváth ${ }^{*}$ and György Pataki
}

\begin{abstract}
This empirical paper presents a case of a participatory agenda-setting exercise for green care services in Hungary. Science Cafés were utilised as a participatory agenda-setting tool within the framework of the InSPIRES H2O2O project. The objectives were to collect perceptions of research needs from key actors in the green care field in Hungary, to generate collaborative research projects on green care services and to initiate social dialogue around green care in Hungary. The main research question was as follows: how can we co-create a research agenda on green care by eliciting responses from concerned citizens and experts in a very open and democratic setting? While a growing body of evidence supports the need for, and benefits of, green care services, there is not much research in Hungary addressing diverse knowledge needs of the multiple social actors in the green care field. Science Café as developed for institutionalising an informal and lively dialogue between science and society proved to be a useful tool to co-generate a research agenda for such a relatively neglected but socially highly beneficial theme as green care.
\end{abstract}

Keywords: Science Café, Science Shop, Responsible Research and Innovation (RRI), Green care, Participatory research agenda-setting

\section{Introduction}

The role of science in society has recently emerged as an 'old-new' topic in the European science, research and innovation context. The proliferation of terms related to science-society interfaces (e.g. citizen science, responsible research and innovation (RRI), science shop, social innovation) demonstrates the potential for creativity and reflexive renewal open to professional scientists and other actors interested in engaging more with science. Furthermore, democracy has been under challenge globally, and science as an institution may well need to critically reflect upon its role in society and the particular grand societal and ecological challenges we all face today. Therefore, competences and skills both for citizens' engagement with science and science's engagement

\footnotetext{
* Correspondence: horvath.janka@essrg.hu

Environmental Social Science Research Group (ESSRG), Impact Hub Budapest, Ferenciek tere 2, Budapest 1053, Hungary
}

with society are needed in order to strengthen democracy in a wider sense.

Part of this challenge to democratise science through meaningful science-society interfaces requires a rethinking of the scientific process as a whole, as well as of each component or phase of the research process. The importance of anticipating societal knowledge needs or the need for research and innovation to be better aligned with societal challenges becomes clear. We argue that if a research process aims at being participatory and responsive, due care should be taken to practice citizen engagement from the very start of the research process. Attending to the responsiveness requirement of RRI by enacting public engagement with science will thus require opening up the research agenda-setting phase to broader participation, both at the research project level and more strategic levels (e.g. national research strategies). The research question we focus on is as follows:
Springer Open

(c) The Author(s). 2020 Open Access This article is licensed under a Creative Commons Attribution 4.0 International License, which permits use, sharing, adaptation, distribution and reproduction in any medium or format, as long as you give appropriate credit to the original author(s) and the source, provide a link to the Creative Commons licence, and indicate if changes were made. The images or other third party material in this article are included in the article's Creative Commons licence, unless indicated otherwise in a credit line to the material. If material is not included in the article's Creative Commons licence and your intended use is not permitted by statutory regulation or exceeds the permitted use, you will need to obtain permission directly from the copyright holder. To view a copy of this licence, visit http://creativecommons.org/licenses/by/4.0/. 
how can we co-create a research agenda on green care by eliciting responses from concerned citizens and experts in a Science Café setting?

This paper reports on our experiences using Science Cafés as a tool to generate a research agenda in a participatory way. Our experience has been gained within the transdisciplinary field of green care. First, we briefly discuss participatory agenda-setting as reflected in the extant literature, particularly in the field of health and environment. Second, we introduce the field of green care. Third, we describe the process for participatory research agenda-setting for green care in Hungary. Fourth, we share our reflections on the experience gained from the Science Café as a participatory research agendasetting tool. Finally, we offer our conclusions.

\section{Participatory research agenda-setting: theoretical and project background}

Stakeholder involvement and public participation in science in general, and in research agenda-setting in particular, have become overlapping interests of researchers in science policy, health research, public engagement, and the political sociology of science. Co-production and sharing power with citizens in the research process in novel forms resonate with diverse traditions and trends in science. In particular, action research (e.g. $[6,10])$, the right to research [3], citizen science [28], and responsible research and innovation (RRI) [20] are becoming the most advanced fields where co-production and the radical democratisation of the research process are most often practised. A range of future-oriented methodologies, tools, and approaches are deployed in this problem space: foresight, backcasting, scenario development, Delphi, trend impact, and horizon scanning (e.g. $[18,21]$ ). Stakeholders in many phases of the processes-from agenda-setting, through research design, to evaluation, and dissemination-can enter, create legitimate roles, and provide meaningful knowledge for research content and focus. Rosa et al. [25] investigate large-scale EU-wide participatory agenda-setting processes (such as CIMULACT H2020-http://www.cimulact.eu/), as compared to expertbased foresight studies. Clearly, citizen-based, multi-actor co-created policy advice differs qualitatively from expert-based reports, in terms of the direction and focus of the proposed R\&I agenda.

Participatory research agenda-setting, as a form of coproduction, is a well-established field in applied healthcare and medical studies, and various such settings, where researchers and patients collaborate have been analysed in detail. Often intermediary organisations bring together patients and researchers to shape a shared problem space for future investigations. Abma and Broerse [2] extract a model (or template approach) for such research agenda-setting exercises, based on seven case studies in the medical sciences. Their Dialogue Model provides a flexible and interactive approach that extends to six research phases: exploration; consultation; prioritisation; integration; programming; and implementation. The dialogue model is defined as 'an interactive, multistakeholder and multiphased process for the coproduction of a shared research agenda. It entails six phases, including the consultation of patients and researchers and the integration of their agendas' ( $p 2$ [1].). By offering a mutually supportive process, it evolves into a 'free, protective and communicative space of mutual encouragement to develop power from within and to articulate' multiple voices, which leads to 'meaningful deliberations' with professionals, researchers and funding agencies ([1], p. 1). The primary motivation is to create a relevant and useful research agenda that better enables healthcare services to meet the needs and expectations of patients. As a primary goal, the dialogue model aims explicitly for patients to reflexively highlight their agenda, by offering an empowering process that also incorporates a broader collaboration with policy-makers, treatment or service providers, citizens, medical doctors and civic groups. It employs several techniques to enable diverse forms of expression: anecdotes, storytelling with others, diaries, photographs, movies and theatre. The main challenge of the model is to trigger permanent changes in research and institutional transformation based, on the one hand, on the enacted participatory processes and, on the other, on the resulting prioritised list of substantive research topics.

Such participatory research agenda-setting exercises can also help to point out 'undone science' [13], defined as 'areas of research that are left unfunded, incomplete or generally ignored, but that social movement or civil society organisations often identify as worthy of more research' (p. 1). The prioritisation phase of these exercises is regarded as the active social construction of knowledge and, therefore, such knowledge co-production also implies a pre-existing inequality, ignorance or systematic nonproduction of knowledge.

Based on a qualitative assessment of nine multistakeholder agenda-setting projects in the Netherlands, Pittens [23] contends that while patients are increasingly involved in health research agenda-setting, their topics and concerns are not automatically translated into a funding programme or taken up by researchers. As a general trend, public participation and beneficiaries' involvement usually stops before research projects are programmed and implemented.

The EU H2020-funded InSPIRES consortium (http:// inspiresproject.com/) aims to narrow the gap between society and science by co-creating and implementing innovative science shop models that are inclusive, context-relevant, culturally adapted and more accurate 
and responsive to civil society concerns. Within the framework of these new models, InSPIRES partners facilitate collaborative research projects aligned with the principles of RRI, Open Science (OS) and Impact Evaluation. There is a particular focus on health and environmental issues, which are underexplored in the current science shop research agenda, yet can be adequately addressed by strengthening community voices and developing the conditions for a participatory dialogue and knowledge sharing. We now turn to the Science Café as a participatory method of public engagement with science and science engagement with the public.

Science Cafés can have multiple purposes and can be applied in different contexts (e.g. [4]). The first series of Science Café events through which our team gained experience was organised between 2004 and 2010 ('Sustainable Hungary Science Café'), aimed at the popularisation of a sustainability science agenda. In this role, it proved to be a useful tool to engage various publics around urgent and vexing sustainability problems in agriculture, forestry, policy, environment, mobility, energy, gender and politics. Subsequently, two EU FP7 projects (SciCafé and SciCafé2.0) assisted us in understanding the evolution of the Science Café movement and how a previously grassroots movement became a public engagement buzzword (for detail, see [4]). The pervasiveness of participatory engagement in research agendas (multi-actor approach, RRI, Citizen Science) led to a situation where such science-society interactions came to be regarded as almost a necessary step in the promotional cycle of scientific production.

The evolution of the Science Café movement has been embedded into the broader context of changing science culture and the emerging practices of science democratisation. Citizenship as a notion in democratic societies contains the engagement of publics in science as well, a prerequisite to controlling our own destiny. Several converging mechanisms of science-society-policy interactions, transdisciplinary and public engagement activities (e.g. action research, participatory research, science café, science shop, citizen science, OS, RRI, social innovation) run parallel in today's science environment. This warrants the need to revisit opportunities for the renewal that Science Cafés can offer in the changing landscapes of scientific culture. Below we present how we applied Science Café in participatory agenda-setting for green care.

\section{Participatory research agenda-setting: our process}

In 2014, our team organised the first platform event on care farming with advocates and practitioners, an antecedent to the research project. This forum provided an open space for joint evaluation of the state of the art in Hungary, sharing best practice examples and previous experiences. After this event, one of the participants launched a Norwegian-funded project aiming to establish the Hungarian care farming system. We contributed to the project as members of the expert group which produced evidence-informed arguments on the diverse benefits green care may bring to society. More recently, joint efforts have resulted in establishing an active platform for green care organisations and state-sponsored resources available to green care service providers. In 2018, within the framework of the InSPIRES H2020 project, we started to focus on the research needs of green care services in the Hungarian context. Our main objectives were to foster the engagement of scientific actors with green care by initiating and facilitating dialogue to prepare a novel research agenda on green care services and generating collaborative research projects.

In the preparatory phase, we conducted desk research on green care services, until recently a neglected field of interest for policy-making and scientific research in Hungary. Our literature review of this field illustrates the unequal knowledge production in the green care literature. An advanced search in the Scopus database with the 'green care' keyword produced 566 documents between 2000-2020. The results show the exponential growth of this research area, reaching 50 articles per year in 2010 and passing 75 articles per year by 2019 . Articles are predominantly from the medical, social and environmental sciences, and exclusively from Western countries: the UK, the Netherlands, the USA, Italy and Norway.

Green care became one of the many concepts that have been circulated in recent years to grasp naturehealth linkages. Already over 10 years ago, a special issue of The International Journal of Therapeutic Communities defined green care as outdoor activities and involvement with nature in a therapeutic context [12]. By green care, we refer to how nature (its elements, like plants, animals and landscapes, or its use and maintenance, through agriculture, gardening, conservation and animal husbandry) can be used to offer well-being and healthpromoting activities for people [14, 26, 27].

Since the 1980s, we, the citizens of highly urbanised and industrialised countries, have spent more than $90 \%$ of our lives indoors, while our time outside has been reduced to $1-5 \%$ [9]. Meanwhile, a growing body of evidence proves that contact with nature enhances human health and well-being $([5,17,24,29,22])$. We identified four critical levels, adapted from the work of Bragg et al. [7], in which a person can interact with nature: (a) nature as part of everyday life (e.g. nature viewed through a window, natural elements as decoration); (b) places and activities in the natural environment experienced as part of health promotion (e.g. jogging, cycling, gardening, hiking, creation and use of healing gardens and therapeutic landscapes); (c) nature engagement activities 
as tools of fostering nature connection and ecological thinking (e.g. school gardens, volunteering in nature conservation or organic farming); and (d) green care services as personally tailored, therapeutic interventions for people with defined needs (e.g. animal-assisted therapy, garden therapy, wilderness therapy, care farms). Green care services focus on the changes in people's wellbeing induced by their connection with nature [15].

In western and northern Europe, green care is an emerging phenomenon, yet there is still a lack of understanding of the term [14]; there are a few types of research which focus on green care in general, as this concept brings together several academic disciplines across health, environmental and social sciences. Green care typically requires work along the boundaries of environmental and social sciences with a transdisciplinary approach. Within the InSPIRES project, we mapped civil society needs and concerns around green care that contained several empirical steps. Table 1 below summarizes the phases of the research agenda-setting process.

In the empirical data-gathering phase, we carried out stakeholder interviews with a sample drawn from our previous contacts, the snowball method and internet search. We conducted 13 expert interviews in total with practitioners in their own work contexts. The average length of the interviews was around one hour. We invited practitioners to describe their experience in green care from the angle that they conceived as most relevant (see Table 2 compiling initiatives and practitioners of green care services, and their specialities in Hungary). We engaged in a discussion of a set of previously identified themes, such as their green care work practices; attitudes towards their clients and the effectiveness of green care services; and expectations for the future and research needs around green care services.
After the initial data gathering through expert interviews, we selected five themes that could well present the whole-systems approach to the broader audience of the Science Café discussions in order to elicit research needs. The themes (animal-assisted therapy, herding therapy, cave therapy, art therapy, wilderness therapy) point out various areas of green care services and highlight virtually invisible or underrepresented themes. During the Science Café sessions, following experts' introductory talks, citizens' theme-related questions and knowledge needs were discussed in informal conversation. Between January and May 2018, we organised five Science Cafés in collaboration with the 'Care Farm Blog', one of the few Hungarian information sources on green care. The criteria for choosing green care service providers relied on the whole-systems approach [8] and the principles of ecopsychology [11]. In practice, we were looking for (a) the sense of a synergistic, holistic relationship between nature and humans; (b) recognition that the belief that we are separated from nature is an illusion which causes suffering both for humans and for the environment; and (c) the perception that a better relationship between humans and nature is healing for both. All the green care services chosen are, in this sense, endeavours to harmonise the nature-human relationship.

Our data analysis followed a qualitative approach to interpret interview data and Science Café texts. Expert interviews and Science Café discussions with experts and practitioners were (audio- and video-) taped, transcribed and thematically categorised. Together with researchers' notes from debriefing sessions, all texts were analysed using a combination of meaning condensation and categorisation [19]. Our results show that citizen and expert ideas generated a shared and novel research agenda. In the research agenda, we gathered critical statements on research needs by experts and citizens as

Table 1 Summary of the main empirical steps in the research agenda-setting process

\begin{tabular}{|c|c|c|c|}
\hline Methodology applied & Number of resources or people involved & Research topics identified & $\begin{array}{l}\text { Actor groups in the research } \\
\text { agenda-setting }\end{array}$ \\
\hline Desk research & $\begin{array}{l}\text { Review of the relevant literature on } \\
\text { green care services and methodologies } \\
\text { for research agenda-setting }\end{array}$ & $\begin{array}{l}\text { Amongst varied form of } \\
\text { co-production, a template } \\
\text { approach-the dialogue model }\end{array}$ & ESSRG researchers \\
\hline Interviews with experts and practitioners & 13 expert interviews & \multirow[b]{2}{*}{$\begin{array}{l}\text { A broad range of green } \\
\text { care fields (circa 8) and } \\
\text { service types. } \\
\text { Five themes: animal-assisted } \\
\text { therapy, herding therapy, } \\
\text { cave therapy, art therapy } \\
\text { and wilderness therapy } \\
\text { Impact evaluation is the } \\
\text { most favoured research need }\end{array}$} & Practitioners and experts \\
\hline $\begin{array}{l}\text { Science Cafés as interface of experts } \\
\text { and citizens }\end{array}$ & $\begin{array}{l}5 \text { sessions with green care professionals, } \\
\text { each inviting } 4-40 \text { participants }\end{array}$ & & $\begin{array}{l}\text { Lay and interested audience of } \\
\text { the Science Cafés in dialogue } \\
\text { with experts and practitioners }\end{array}$ \\
\hline Outreach activities & $\begin{array}{l}\text { Podcasts and videos to extend the } \\
\text { impact, widening stakeholder outreach }\end{array}$ & $\begin{array}{l}\text { Summary of articulated } \\
\text { research needs }\end{array}$ & $\begin{array}{l}\text { ESSRG researchers' collaboration } \\
\text { with universities to formulate } \\
\text { research questions and respond } \\
\text { to them }\end{array}$ \\
\hline
\end{tabular}


Table 2 A compilation of initiatives and practitioners, listing the different kinds of green care services, with examples and references to research/practice specialties in Hungary

\begin{tabular}{ll}
\hline Type of green care service & Specialty \\
\hline Animal-assisted therapy & Connection-centred animal-assisted therapy (method developed by the expert) \\
Animal-assisted therapy & Herding therapy with goats and sheep (method developed by the expert) \\
Animal-assisted therapy & Therapeutic work with horses, provided by a clinical psychologist \\
Animal-assisted therapy & Therapeutic work with horses specialised for children \\
Healing garden/garden therapy & Autism-specific garden \\
Healing garden & Healing garden for patients in a courtyard of a hospital \\
Wilderness therapy & Wilderness therapy programs for youngsters in childcare \\
Wilderness therapy & Therapeutic caving tours for children/youngsters with special needs \\
Ecotherapy & Ecotherapy sessions for people with mental health issues \\
Care farming & Providing services for children with special needs at an ecological farm \\
Green exercise & Hiking trails for people with cardiovascular diseases
\end{tabular}

well as their overlapping components. The common elements of citizens' and experts' expectations for future green care services research are a summary of scientific evidence on green care services; methodological handbooks and case study collections including Hungarian green care initiatives; a search for good international practices; promotion of green care services and reaching out to potential beneficiaries; and, finally, monitoring of green care processes. The primary need that emerged is the validation of the impacts of green care services.

As a final outreach step, we approached researchers in various fields (medical, psychological) and institutions of higher education in Hungary with research ideas based on this novel agenda, and a new action and research plan was constructed to deploy an impact evaluation process in a Hungarian school garden [16]. We paid particular attention to follow-up activities, such as feedback interviews with the invited experts, and podcasts and videos to promote the topic and to provide opportunities for citizens and professionals to join our process afterwards (all videos and podcasts are available with English subtitles at https://tinyurl.com/essrg-sciencecafe).

\section{Discussion}

The main result of the Science Cafés on the content level is the emergence of divergent themes around green care services. Still, all actor groups believe that there is a need for creating legitimate knowledge around green care (see Fig. 1 below). Experts seek to create and distil scientific evidence on green care services as well as methodological and case study repositories for the benefit of research on Hungarian green care initiatives. The lack of comparative studies, of more embedded case study research and of international knowledge sharing is a hindrance to the development of this field. Practitioners are interested in the successful promotion of green care services and reaching out to potential beneficiaries. Experts and practitioners would both favour monitoring studies of green care processes. Citizens and experts agree that the impact evaluation of green care services is of primary importance to better establish this field.

Following the model presented by Abma and Broerse [2], we showed that Science Cafés provide a flexible and interactive space for agenda-setting exercises-especially in the exploratory phase. The events created 'meaningful deliberations' [1] between experts, practitioners and lay audiences on substantive research topics for green care. The agenda-setting exercise also pointed out that several preferred research questions, often left ignored by health research, are practically 'undone science' [13]. The topics raised and concerns identified during the Science Cafés can be taken up by researchers. Our exercise is part of a science shops strategy to co-create research agendasthe one which, in the long run, has some potential impact to inspire change in national funding schemes.

The novelty of this research agenda-setting process was a systematic mapping of Hungarian research and civic organisations and experts that offer green care services. Our expert interviews identified unique initiatives; for instance, a clinical psychologist who developed a unique way to involve 'wild', not too socialised farm animals into her therapeutic work, and a group of professional cavers who have been holding cave therapy sessions for children with special needs for almost 20 years.

The Science Cafés used in our agenda-setting were able to introduce multiple topics and invite creative arrangements. The essence of the Science Café events was to create an open, encouraging and informal platform around green care, and to build a bridge between society and science. To achieve this target, we held the Science Cafés in a small, centrally located café (in Budapest), and advertised them on the Facebook page of the 'Care Farm 


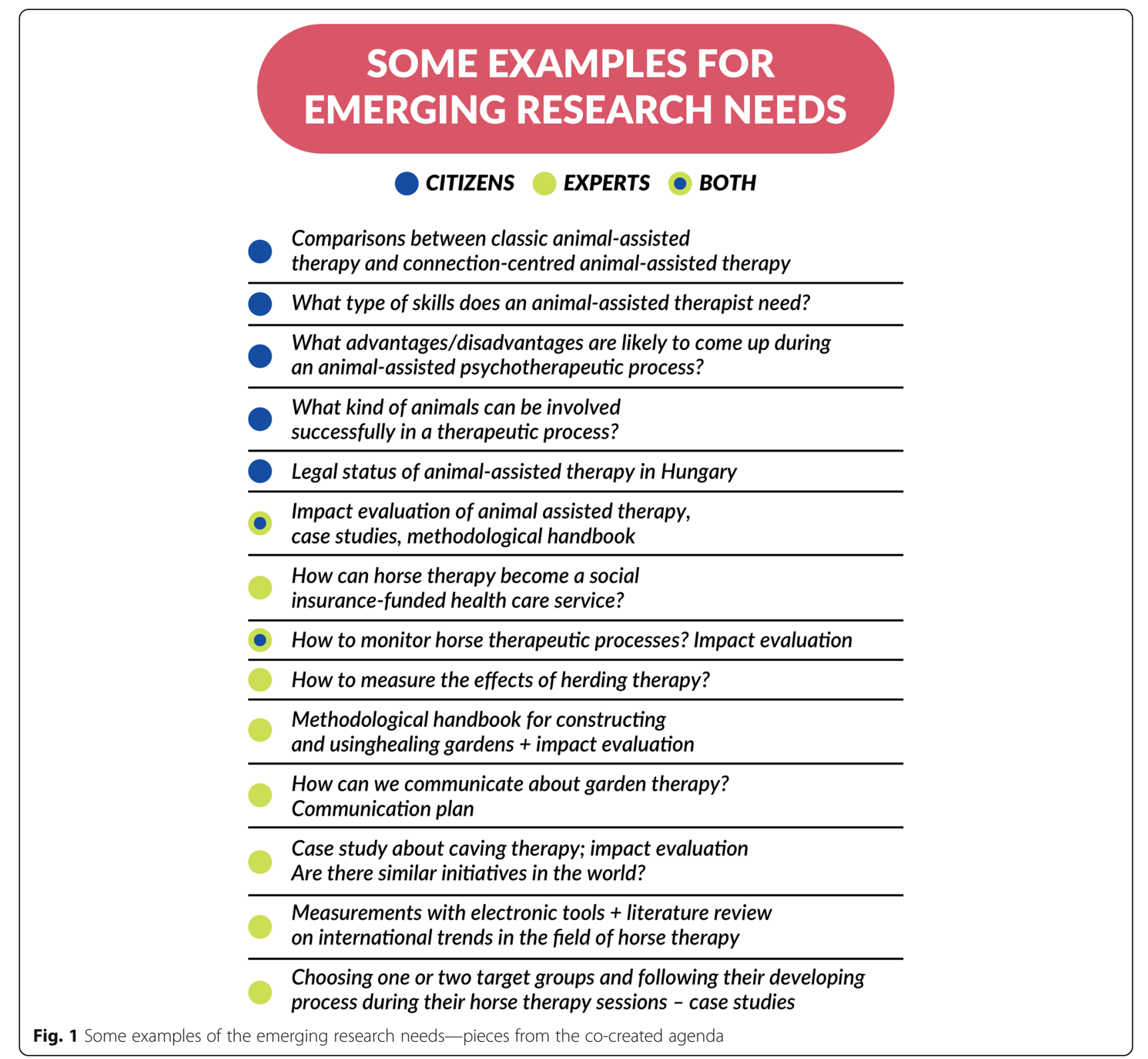

Blog' and through flyers and posters placed in the café, in the nearest public library, at some of the universities located in Budapest and in the Impact Hub Budapest, where our office is situated. Anyone who felt connected to the green care-related topics could come and join us for a chat. Due to the open and inclusive setting, we did not introduce a registration process; therefore, we do not have detailed information about the attendees. Based on informal talks before and after the events and on the articulated questions, we determined that they were mainly university students, educators and professionals already interested in green care and possessed of some personal ambition to deal with green care in the future. We enhanced the friendly, relaxed atmosphere by rearranging the furniture of the café to provide a circular space for interaction, not just frontal listening. We also encouraged the experts beforehand to prepare for a discussion, not a lecture. The chosen experts demonstrated excellent communication skills, flexibility and openmindedness, and they were keen to talk about their work. The scripting of the event supported this idea: the expert could talk about his/her job for 20-25 min, then there was one hour available for a dialogue about the emerging issues with the assistance of a facilitator (one of the co-authors of this paper). The facilitator's principal duty was to elicit questions from the audience and invite everyone to freely share their thoughts and emotions in connection with the subject.

To identify the converging views, each question or comment from the audience posed to the experts was 
operationalised as an articulated research need. Several research needs were shared by both the experts and the citizens, as enumerated in Fig. 1. The participants' questions were quite technical and professional; more personal questions might have been raised if there had been fewer attendees. From both the citizens' and the experts' side, a strong demand for impact evaluation research was apparent. Following upon this particular research need, we have successfully initiated an action research project on impact assessment in a grammar school near Budapest [16]. Moreover, we derived new research questions from the contributions and initiated cooperation with relevant university faculties to respond to them, with the inclusion of university students (particularly in the medical and psychological fields).

As for the divergent views, the difference is principally rooted in the distinct approach we, as researchers, took to inviting the attendees into the process. In the interviews with experts, we asked them to respond to the following questions: What do they need from science? How can we, as researchers, as scientists, support their work? Unsurprisingly, they gave us mainly researchrelated answers. In contrast, citizens were invited to an informal quasi-scientific conversation, where the terms 'participatory agenda-setting' or 'research needs' were not explicitly articulated at all. Their contributions related to the specific service the expert presented during the event. Thus, they were interested in the technical details of the therapeutic process. They were also curious about the process by which they could become green care service providers in the future.

Every minor decision affected the whole process, from the selection of presenting experts, the way we promoted the events, the venue and dates we chose, the way we arranged the furniture to the manner in which the events were facilitated. We started the series in January 2018, when the weather was dark and cold, and there were around 40 participants; yet when the final Science Café was held in May 2018, only four people participated. We can partly blame the beautiful weather or the theme of the last event for the significant decline, but, looking at the entire process, we can ascertain that it might have run too long. We organised one event every month between January and May. Thus, a decline was to be anticipated.

Reflecting on the process, we can state that the emerging research needs could have been different if we had targeted the Science Cafés solely towards health and social care professionals, or if we had a number of attendees and discussed deeper, more personal, themerelated issues. The first option would have yielded more insights into the experts' research needs and could have created a research agenda for professionals, while the second would have collected the potential green care service users' claims, feelings, thoughts and concerns about these supplementing therapeutic services. Still, we believe that plenty of valuable knowledge needs have surfaced, and that we will be able to implement the research priorities in the second phase of this process.

\section{Conclusion}

Disconnectedness from nature presents an academic interest that has long traditions in environmental social sciences. There is already substantial evidence for the social and human health benefits of nature contact, but several research questions and domains concerning the preventive and/or therapeutic use of green approaches remain unanswered and open. Therefore, a research agenda-setting exercise is helpful to put forward future research suggestions. Science Cafés bringing together citizens and professionals in the assessment of research fields can help identify some novel and critical areas for future research. Furthermore, the events and the subsequent outreach activities created reflection on and momentum for pressing research needs. Green care as a preventive and/or therapeutic potential of nature is rarely present as a prescribed intervention for patients in healthcare. In particular, our Science Cafés illustrated that more robust, evidence-based and thorough research would be necessary on the impact of green care services to make their use in healthcare more legitimate. We recommend that researchers seek to develop embedded case studies, comparative and longitudinal studies of green care service providers and their work. As we have shown, knowledge production in this area is increasing, but the concept itself still lacks a clear analytical framework. The most pressing knowledge needs in this new area of inquiry are all related to the impact assessment of green care service provision.

Becoming relevant and responsive to societal needs in our scientific activities, and to societal expectations of us, is an urgent challenge. Researchers can draw on a long tradition of participatory worldviews in science, enacted prominently by action research, post-normal and trans-disciplinary approaches. There is an embryonic creative search for and development of new ways of producing knowledge at the science-society interface. However, the nature of participation is dynamic. Not everyone would like to participate. The dimensionality in engagement gains significance: inequities in who is involved and how, and who is not involved, necessarily create biassed knowledge production and create and maintain unequal power relations. The responsibility of researchers is, therefore, high, in their choice of processes and tools for enacting societal engagement and citizen participation in science.

Several contextual factors, such as positive attitudes towards involvement, good relations amongst stakeholders, 
and supportive organisations, can successfully enable participatory agenda-setting and research implementation. The main ambition of participatory research agenda-setting-to enable future research and innovation to better align with societal values and demands-is essential to gaining more democratic legitimacy, beyond expert- or technology-driven processes. In the emerging EU research context, participatory agenda-setting is becoming a practical tool to implement RRI, and a possible solution to the challenge of including laypeople in research governance.

The main lesson we learned from this process is that a low-cost method like organising Science Cafés can be applied in the prioritisation phase of a research agendasetting exercise in an inspiring and convivial way. As our experience has demonstrated, maintaining relations with social actors and stakeholders remains a crucial challenge for research agenda-setting exercises in the later phases of implementation. Science Cafés with diverse audiences can be particularly useful in seeking more opportunities utilizing meaningful openness and adaptive change in their process to achieve a citizens' role in coproducing novel and pertinent research agendas. However, our particular experience with employing Science Cafés for research agenda-setting shows that mainly citizens of a particular professional interest (e.g. students, teachers, practitioners) tend to become engaged, rather than citizens with a general interest.

Based on our experiences, following the RRI process requirements, it can be seen that it is desirable to involve citizens with experts in a mutually responsive way to map actually existing societal concerns about and knowledge needs for an emerging research field. Sharing and reflecting upon experiences in real-life experiments at the science-society interface is of high significance to all of us in our efforts to enact democracy in science.

\section{Abbreviations}

RRI: Responsible Research and Innovation; OS: Open Science;

ESSRG: Environmental Social Science Research Group

\section{Acknowledgements}

We are grateful to all who contributed to this process, to those green care experts and researchers who cooperated with us and to those citizens who attended our Science Cafés and co-created a lively learning atmosphere. We are grateful for what we learned from discussions within the InSPIRES consortium and our ESSRG team.

\section{Authors' contributions}

Authors are listed alphabetically and have contributed equally in the research and writing of this article. The authors read and approved the final manuscript.

\section{Funding}

Our participatory agenda-setting process is funded by the InSPIRES project. The project has received funding from the European Union's Horizon 2020 research and innovation programme under grant agreement no. 741677 .

\section{Availability of data and materials}

All videos of the green care Science Café events are available with English subtitles at https://tinyurl.com/essrg-sciencecafe
Ethics approval and consent to participate

Not applicable.

\section{Consent for publication}

Not applicable.

\section{Competing interests}

The authors declare that they have no competing interests.

Received: 29 July 2019 Accepted: 2 June 2020

Published online: 13 July 2020

\section{References}

1. Abma TA (2018) Dialogue and deliberation: new approaches to including patients in setting health and healthcare research agendas. Action Res 1476750318757850

2. Abma TA, Broerse JE (2010) Patient participation as dialogue: setting research agendas. Health Expect 13(2):160-173

3. Appadurai A (2006) The right to research. Globalisation, Societies and Education 4(2):167-177

4. Balázs, B. (2016). Science cafés: beyond buzzwordification. Did a grassroot movement turn into a buzzword for public engagement? SPOKES \#24. (November).

5. Barton J, Hine R, Pretty J (2009) The health benefits of walking in greenspaces of high natural and heritage value. Journal of Integrative Environmental Sciences 6(4):261-278

6. Bradbury H (ed) (2015) The Sage Handbook of Action Research. Newbury Park, Calif, Sage

7. Bragg R, Wood C, Barton J, Pretty J (2014) Wellbeing benefits from natural environments rich in wildlife: a literature review for The Wildlife Trusts. London, The Wildlife Trusts URL: https://wild lifetrusts.org/sites/default/files/2 01805/r1_literature_review_wellbeing_benefits_of_wild_places_Ires.pdf

8. Buzzell L (2016) The many ecotherapies. In: Jordan, M., and Hinds, J. (eds). Ecotherapy. Theory, research and practice. Palgrave, London, pp 70-82

9. Chalquist C (2009) A look at the ecotherapy research evidence. Ecopsychology 1:1-12

10. Chevalier JM, Buckles DJ (2019) Participatory action research: theory and methods for engaged inquiry. Routledge, London, New York

11. Davis J. (2006): Ecopsychology defined. Naropa University. Boulder, Colo. URL: http://www.soulcraft.co/essays/ecopsychology.html.

12. Freestone, M. et al. (2008). Therapeutic communities: green care edition. International Journal of Therapeutic Communities. 29(3). (Autumn).

13. Frickel S, Gibbon S, Howard J, Kempner J, Ottinger G, Hess DJ (2010) Undone science: charting social movement and civil society challenges to research agenda setting. Science, Technology, \& Human Values 35(4):444-473

14. Haubenhofer DK, Elings M, Hassink J, Hine RE (2010) The development of green care in western European countries. Explore 6(2):106-111

15. Hinds, J., and Jordan, M. (2016). Ecotherapy: an introduction. In: Jordan, M. and Hinds, J. (eds). Ecotherapy. Theory, research and practice. Palgrave. London. 1-10.

16. Horváth, J., and Kelemen, E. (2019): How to assess the healing power of nature? Impact evaluation process in a Hungarian school garden. URL: http://inspiresproject.com/isginspiring/how-to-assess-the-healing-power-ofnature-impact-evaluation-process-in-a-hungarian-school-garden/

17. Kaplan R, Kaplan S (1989) The experience of nature: a psychological perspective. Cambridge University Press, Cambridge, UK

18. Király G, Pataki G, Köves A, Balázs B (2013) Models of (future) society: bringing social theories back in backcasting. Futures 51:19-30

19. Kvale, S (1996) InterViews: an introduction to qualitive research interviewing Sage.

20. Mejlgaard, N. et al. (2018). Monitoring the evolution and benefits of responsible research and innovation in Europe: summarising insights from the MoRRI project. URL: http://www.technopolis-group.com/wp-content/ uploads/2018/05/Final_report_MoRRl.pdf

21. Mihók B et al (2015) Bridging the research-practice gap: conservation research priorities in a Central and Eastern European country. Journal for Nature Conservation 28:133-148

22. Natural England. (2016). Links between natural environments and mental health. URL: http://www.publications.naturalengland.org.uk/publication/ 5748047200387072 . 
23. Pittens CA, Elberse JE, Visse M, Abma TA, Broerse JE (2014) Research agendas involving patients: factors that facilitate or impede translation of patients' perspectives in programming and implementation. Sci Public Policy 41(6):809-820

24. Pretty J (2004) How nature contributes to mental and physical health. Spirituality and Health International 5:68-78

25. Rosa A, Gudowsky N, Warnke P (2018) But do they deliver? Participatory agenda setting on the test bed. European Journal of Futures Research 6(1):14

26. Sempik J, Bragg R (2013) Green care: origins and approaches. In: Gallis C (ed) Green care: for human therapy, social innovation, rural economy, and education. Nova Science Publishers, New York

27. Steigen AM, Kogstad R, Hummelvoll JK (2015) Green care services in the Nordic countries: an integrative literature review. Eur J Soc Work 19(5):692-715

28. Strasser B, Baudry J, Mahr D, Sanchez G, Tancoigne E (2019) 'Citizen Science'? Rethinking science and public participation. Sci Technol Stud 32: $52-76$

29. Ulrich RS (1991) Stress recovery during exposure to natural and urban environments. J Environ Psychol 11:201-230

\section{Publisher's Note}

Springer Nature remains neutral with regard to jurisdictional claims in published maps and institutional affiliations.

\section{Submit your manuscript to a SpringerOpen ${ }^{\circ}$ journal and benefit from:}

- Convenient online submission

- Rigorous peer review

- Open access: articles freely available online

High visibility within the field

- Retaining the copyright to your article

Submit your next manuscript at $\boldsymbol{\nabla}$ springeropen.com 